\title{
PENGARUH KEPEMIMPINAN DAN KEMAMPUAN SDM TERHADAP EFEKTIVITAS PELAYANAN PENSERTIFIKATAN HAK ATAS TANAH PADA KANTOR PERTANAHAN KOTA TANGERANG
}

\author{
Dudung Hadiwijaya, Rabitha Fazira \\ dudunghadiwijaya@ rocketmail.com, rabithafazira@gmail.com \\ Dosen Fakultas Ekonomi dan Bisnis Program Studi Manajemen \\ Universitas Muhammadiyah Tangerang
}

\begin{abstract}
The purpose of the research is to examine the influence of the leadership and HR ability to the service effectiveness of the land property rights at Agrarian Office of Tangerang City. The result of the research indicate that the leadership and HR ability are together have significant effect toward service effectiveness. The result also indicates that the leadership have more dominant and significant effect than HR ability towards the service effectiveness of the land property rights at Agrarian Office of Tangerang City.
\end{abstract}

Keywords: the leadership, HR ability, service effectiveness

\section{PENDAHULUAN}

\subsection{Latar Belakang Masalah}

Pensertifikatan tanah merupakan salah satu kegiatan pembangunan pertanahan dalam bentuk pelayanan kepada masyarakat. Dalam Pasal 19 Undang-undang Nomor 5 Tahun 1960 tentang Peraturan Dasar Pokok-pokok Agraria (UUPA) menetapkan bahwa untuk menjamin kepastian hukum oleh Pemerintah diadakan pendaftaran tanah di seluruh wilayah Republik Indonesia.
Peraturan Presiden Nomor 10 Tahun 2006 menjjelaskan bahwa Badan Pertanahan Nasional Republik Indonesia (BPN-RI) adalah Lembaga Pemerintah Non Departemen yang berada dibawah dan bertanggungjawab kepada Presiden, sedangkan Kantor Pertanahan mempunyai tugas antara lain melaksanakan sebagian tugas Badan Pertanahan Nasional di wilayah Kabupaten/ Kota.

Masyarakat selama ini beranggapan bahwa sangat sulit memahami pelayanan yang diselenggarakan oleh birokrasi 
publik. Masyarakat pengguna jasa sering dihadapkan pada begitu banyak ketidakpastian ketika mereka berhadapan dengan birokrasi. Sangat sulit memperkirakan kapan pelayanan itu bisa diperolehnya. Begitu pula dengan biaya dan waktu seringkali tidak bisa terjangkau oleh masyarakat sehingga banyak orang yang kemudian enggan berurusan dengan birokrasi publik.

Desakan itu tidak hanya menyangkut kecepatan pelayanan saja, akan tetapi juga hal-hal lain seperti transparansi prosedur, biaya, waktu yang sudah semestinya dijelaskan masyarakat yang dalam hal ini berfungsi sebagai pelanggan. Tuntutan tersebut berlaku untuk semua jasa pelayanan termasuk pelayanan publik seperti Badan Pertanahan Nasional yang layanan utamanya adalah memberikan sertifikat hak atas tanah sebagai bukti kepemilikan tanah.

Pada hakekatnya Kantor Pertanahan Kota Tangerang telah berupaya melakukan tugas pokok dan fungsinya dengan sebaik-baiknya, namun pelaksanaan tugas pokok dan fungsi tersebut belum sepenuhnya terlaksana secara optimal karena adanya berbagai kendala dan keterbatasan sarana dan prasarana kantor. Untuk itu Kantor
Pertanahan Kota Tangerang berusaha terus menerus melakukan perbaikan kinerja dengan cara memaksimalkan pelayanan prima baik melalui penyederhanaan sistem pelayanan, peningkatan kualitas sumber daya manusia maupun pembuatan kebijakan dan peraturan-peraturan. Pelayanan prima tersebut dalam pelaksanaannya di Kantor Pertanahan telah dituangkan dalam lampiran Keputusan Kepala Badan Pertanahan Nasional Nomor 1 Tahun 2005 tentang Standar Prosedur Operasi Pengaturan dan Pelayanan (SPOPP).

Walaupun sudah diberlakukan Standar Prosedur Operasi Pengaturan dan Pelayanan (SPOPP), namun kenyataannya waktu penyelesaian tidak bias tepat sesuai dengan SPOPP yang distandarkan, sehingga pelayanan pensertifikatan hak atas tanah yang ada di Kantor Pertanahan Kota Tangerang dianggap kurang efektif, dilihat dalam tabel 1 .

Tabel 1.

\section{Standard Prosedur Operasi \\ Pengaturan dan Pelayanan Seksi/Sub.Bag Hak Tanah dan Pendaftaran Tanah Di lingkungan Badan Pertanahan Nasional}

\begin{tabular}{|ll|c|c|}
\hline Jenis Kegiatan & Standard & Realita \\
\hline $\begin{array}{l}\text { 1. } \\
\text { Konversi melalui: } \\
\text { - Penegasan hak }\end{array}$ & 120 hari & 160 hari \\
\hline
\end{tabular}




\begin{tabular}{|c|c|c|}
\hline $\begin{array}{l}\text { - Pengakuan hak } \\
\text { 2. Peralihan hak } \\
\text { 3. Roya } \\
\text { 4. Hak Tanggungan } \\
\text { 5. Perolehan hak } \\
\text { karena Waris } \\
\text { 6. Pendaftaran SK } \\
\text { 7. Pendaftaran } \\
\text { SKPT } \\
\text { 8. Pendf. Sert. } \\
\text { Hilang } \\
\text { 9. Peningkatan \& } \\
\text { penurunan hak } \\
\text { 10. Pemisahan \& } \\
\text { penggabungan } \\
\text { Tanah yang } \\
\text { bersertifikat } \\
\text { 11. Pemberian Hak } \\
\text { Atas Tanah }\end{array}$ & $\begin{array}{r}120 \text { hari } \\
20 \text { hari } \\
7 \text { hari } \\
7 \text { hari } \\
20 \text { hari } \\
20 \text { hari } \\
6 \text { hari } \\
50 \text { hari } \\
20 \text { hari } \\
35 \text { hari } \\
120 \text { hari }\end{array}$ & $\begin{array}{r}160 \text { hari } \\
22 \text { hari } \\
7 \text { hari } \\
7 \text { hari } \\
25 \text { hari } \\
30 \text { hari } \\
10 \text { hari } \\
60 \text { hari } \\
30 \text { hari } \\
35 \text { hari } \\
180 \text { hari }\end{array}$ \\
\hline
\end{tabular}

Sumber: Kantor Pertanahan Kota

Tangerang, 2014

Dari uraian tersebut di atas maka penulis berasumsi bahwa untuk mengefektifkan pelayanan pensertifikatan hak atas tanah pada Kantor Pertanahan Kota Tangerang, maka dugaan faktor-faktor yang berpengaruh adalah kepemimpinan dan kemampuan sumber daya manusia.

Pada dasarnya penelitian tentang efektivitas pelayanan pensertifikatan hak atas tanah penting untuk dilakukan, dikarenakan masyarakat sebagai pelanggan belum merasa puas terhadap pelayanan yang selama ini diberikan.

\subsection{Perumusan Masalah}

Berdasarkan latar belakang
masalah yang telah diuraikan
sebelumnya, maka penulis merumuskan

masalah sebagai berikut: "Apakah faktor kepemimpinan dan kemampuan SDM berpengaruh positif dan signifikan terhadap efektivitas pelayanan pensertifikatan hak atas tanah pada Kantor Pertanahan Kota Tangerang?".

\subsection{Hipotesis}

Berdasarkan latar belakang masalah yang telah dipaparkan maka penulis merumuskan hipotesis sebagai berikut: "Faktor kepemimpinan dan kemampuan SDM berpengaruh positif dan signifikan terhadap efektivitas pelayanan pensertifikatan hak atas tanah pada Kantor Pertanahan Kota Tangerang".

\subsection{Tujuan Penelitian}

Untuk mengetahui dan menganalisis pengaruh kepemimpinan dan kemampuan SDM terhadap efektivitas pelayanan pensertifikatan hak atas tanah pada Kantor Pertanahan Kota Tangerang

\section{METODE PENELITIAN}

\subsection{Definisi Operasional Variabel}

Definisi variabel-variabel yang diteliti adalah sebagai berikut:

a. Variabel Dependen (Y): Efektivitas Pelayanan. 
Efektivitas Pelayanan merupakan suatu keadaan yang menunjukkan tingkat keberhasilan kegiatan manajemen dalam usaha mencapai tujuan yang telah ditetapkan.

b. Variabel Independen $\left(\mathrm{X}_{1}\right)$ : Kepemimpinan.

Kepemimpinan merupakan kemampuan seseorang mempengaruhi perilaku orang lain untuk berpikir dan berperilaku dalam rangka perumusan dan pencapaian tujuan organisasi di dalam situasi tertentu.

c. Variabel Independen $\left(\mathrm{X}_{2}\right)$ : Kemampuan SDM.

Kemampuan SDM merupakan kondisi seorang pegawai yang mempunyai pengetahuan, keterampilan, pengalaman kerja serta keminatan dalam melakukan suatu pekerjaan yang dibebankan kepadanya sehingga dapat melaksanakan tugas tepat dan benar sesuai dengan tujuan yang diharapkan.

\subsection{Skala Pengukuran Variabel}

Pengukuran pengaruh kepemimpinan dan kemampuan SDM terhadap efektivitas pelayanan di Kantor Pertanahan Kota Tangerang melalui skala Likert digunakan dengan lima tingkatan yang diberi skor sebagai berikut (Sugiyono, 2004:86):

a) Sangat setuju diberi skor lima

b) Setuju diberi skor empat

c) Ragu-ragu diberi skor tiga

d) Tidak setuju diberi skor dua

e) Sangat tidak setuju diberi skor satu.

\subsection{Populasi dan Sampel}

a. Populasi

Populasi dalam penelitian ini, terdiri dari semua elemen yang terkait yakni seluruh pegawai pada Kantor Pertanahan Kota Tangerang.

\section{b. Sampel}

Adapun dalam penentuan sampel pada penelitian ini, responden yang diambil sejumlah 50 orang yang ditujukan pada Pegawai Kantor Pertanahan Kota Tangerang yang tidak mempunyai jabatan struktural (tidak sebagai unsur pimpinan).

\subsection{Metode Analisis Data}

\section{a. Analisis Desktriptif}

Metode analisis deskriptif adalah metode penganalisaan yang dilakukan dengan cara menentukan data, mengumpulkan data, dan menginterpretasikan data sehingga dapat memberikan gambaran masalah yang dihadapi. 


\section{b. Analisis Kuantitatif}

1. Analisis Regresi Berganda

Analsis regresi berganda digunakan untuk mengetahui besarnya hubungan dan pengaruh variabel independen (kepemimpinan dan kemampuan SDM) terhadap variabel dependen (efektivitas pelayanan).

$\mathrm{Y}=\mathrm{a}+\mathrm{b}_{1} \mathrm{X}_{1}+\mathrm{b}_{2} \mathrm{X}_{2}+\mathrm{e}$

Keterangan:

$$
\begin{array}{ll}
\mathrm{Y} & =\text { Efektivitas pelayanan } \\
\mathrm{a} & =\text { Konstanta } \\
\mathrm{b}_{1}, \mathrm{~b}_{2} & =\text { Koefisien regresi } \\
\mathrm{X}_{1} & =\text { Kepemimpinan } \\
\mathrm{X}_{2} & =\text { Kemampuan SDM } \\
\mathrm{e} & =\text { Standar error }
\end{array}
$$

\section{Uji Serempak (Uji F)}

Pengujian ini dimaksudkan untuk mengetahui apakah terdapat pengaruh secara bersama-sama variabel bebas terhadap variabel terikat. Uji F dilakukan secara serentak untuk membuktikan hipotesis awal tentang pengaruh kepemimpinan $\left(\mathrm{X}_{1}\right)$ dan kemampuan SDM $\left(X_{2}\right)$ sebagai variabel bebas, terhadap efektivitas pelayanan (Y) sebagai variabel terikat.

Pengambilan keputusannya dengan membandingkan nilai $F_{\text {hitung }}$ dengan nilai $\mathrm{F}_{\text {tabel. }}$. Bila $\mathrm{F}_{\text {hitung }}$ lebih besar dari nilai $\mathrm{F}_{\text {tabel }}$ maka dapat disimpulkan bahwa variabel bebas dalam model mempengaruhi variabel terikat.

Model hipotesis yang digunakan adalah:

$\mathrm{H}_{0}: \quad \mathrm{b}_{1}=\mathrm{b}_{2}=0$ artinya variabel bebas $\left(\mathrm{X}_{1}, \mathrm{X}_{2}\right)$ secara bersama-sama tidak berpengaruh positif dan signifikan terhadap variable terikat (Y).

H0: $b_{1} \neq b_{2} \neq 0$ artinya variabel bebas $\left(\mathrm{X}_{1}, \mathrm{X}_{2}\right)$ secara bersama-sama berpengaruh positif dan signifikan terhadap variabel terikat (Y).

Nilai $F_{\text {hitung }}$ akan dibandingkan dengan nilai $F_{\text {tabel }}$ Kriteria pengambilan keputusan, yaitu: $\mathrm{H}_{0}$ diterima bila $\mathrm{F}_{\text {hitung }}<\mathrm{F}_{\text {tabel }}$ pada $\alpha=$ $5 \% \mathrm{H}_{0}$ ditolak bila $\mathrm{F}_{\text {hitung }}>\mathrm{F}_{\text {tabel }}$ pada $\alpha=5 \%$.

3. Uji Secara Parsial (Uji-t)

Yaitu sebagai uji signifikan individual. Uji ini menunjukkan bagaimana pengaruh dalam menerangkan variasi variabel terikat.

Bentuk pengujiannya adalah:

$\mathrm{H}_{0}: \mathrm{b}_{1}=0$ 
Artinya, suatu variabel independen bukan merupakan penjelas yang signifikan terhadap variabel dependen.

$\mathrm{H}_{0}: \mathrm{b}_{1} \neq 0$

\begin{tabular}{|c|c|}
\hline Model & Adjusted R Square \\
\hline 1 & .941 \\
\hline
\end{tabular}

a. Predictors: (Constant), Kemampuan_SDM, Kepemimpinan

\section{HASIL DAN PEMBAHASAN}

a. Pengujian Koefisien Determinasi $\left(\mathbf{R}^{2}\right)$

Pengujian dengan menggunakan uji koefisien determinasi $\left(\mathrm{R}^{2}\right)$ atau Goodness of Fit Test, yaitu untuk melihat besarnya pengaruh variabel bebas yaitu kepemimpinan $\left(\mathrm{X}_{1}\right)$ dan kemampuan SDM $\left(\mathrm{X}_{2}\right)$ terhadap variabel terikat yaitu efektivitas pelayanan (Y). Nilainya adalah $0-1$. Semakin mendekati nol berarti model tidak baik atau variasi model dalam menjelaskan dengan sangat terbatas, sebaliknya semakin mendekati satu maka suatu model akan semakin baik.

Tabel 2. Pengujian Godness of Fit Model Summary(b)

Tabel 2 menunjukkan angka Adjusted R Square $\left(\mathrm{R}^{2}\right)$ sebesar 0,941 berarti variabel independen yaitu kepemimpinan $\left(\mathrm{X}_{1}\right)$ dan kemampuan SDM $\left(\mathrm{X}_{2}\right)$ mampu menjelaskan sebesar 94,1\% efektivitas pelayanan (Y).

b. Uji Secara Serempak/simultan (Uji F) atau ANOVA 
Uji F menunjukkan apakah semua variabel bebas (X) yang dimasukkan dalam model mempunyai pengaruh secara bersama-sama terhadap variabel terikat (Y).

Tabel 3. Uji Regresi Secara Bersamasama (Uji-F) ANOVA(b)

\begin{tabular}{|l|c|c|}
\hline Model & F & Sig. \\
\hline 1 Regression & 390.749 & $.000^{\mathrm{a}}$ \\
Residual & & \\
Total & & \\
\hline
\end{tabular}

a. Predictors: (Constant),

Kemampuan_SDM, Kepemimpinan

b. Dependent Variable:

Efektivitas_Pelayanan

Tabel 3 memperlihatkan nilai $F_{\text {hitung }}$ adalah 390,749 dengan tingkat signifikansi 0,000. Sedangkan $F_{\text {tabel }}$ pada tingkat kepercayaan 95\% $(\alpha=0,05)$ adalah 3,195. Oleh karena pada kedua perhitungan yaitu $\mathrm{F}_{\text {hitung }}>\mathrm{F}_{\text {tabel }}$ dan tingkat signifikansi $(0,000)<0,05$, menunjukkan bahwa pengaruh variabel independen yaitu kepemimpinan dan kemampuan SDM secara bersama-sama adalah signifikan terhadap efektivitas pelayanan.

\section{c. Uji Secara Parsial (Uji-t)}

Uji-t digunakan untuk menentukan seberapa besar pengaruh variabel bebas secara parsial terhadap variabel terikat secara individu.
Tabel 4. Uji Regresi secara Parsial (Uji-t) Coefficients(a)

\begin{tabular}{|l|r|r|}
\hline \multirow{2}{*}{ Model } & \multicolumn{2}{|c|}{$\begin{array}{c}\text { Unstandardized } \\
\text { Coefficients }\end{array}$} \\
\cline { 2 - 3 } & \multicolumn{1}{|c|}{ B } & Std. Error \\
\hline 1 (Constant) & -1.442 & .289 \\
Kepemimpinan & .704 & .109 \\
Kemampuan_SDM & .663 & .142 \\
\hline
\end{tabular}

a. Dependent Variable: Efektivitas_Pelayanan

Berdasarkan hasil uji-t maka diperoleh persamaan regresi:

$$
Y=-1,442+0,704 X_{1}+0,663 X_{2}
$$

Hasil penelitian pada Tabel 4 dapat diinterpretasikan sebagai berikut:

1. Variabel kepemimpinan berpengaruh secara positif dan signifikan terhadap efektivitas pelayanan, hal ini terlihat dari nilai signifikan $(0,000)<0,05$ dan nilai $t_{\text {hitung }}(6,476)>t_{\text {tabel }}(2,012)$ artinya jika ditingkatkan variabel kepemimpinan sebesar satu satuan maka efektivitas pelayanan akan meningkat sebesar 0,704. Hal ini menunjukkan bahwa semakin meningkatnya kepemimpinan maka efektivitas pelayanan akan lebih tinggi pula pelayanan pensertifikatan hak atas tanah pada Kantor Pertanahan Kota Tangerang.

2. Variabel kemampuan SDM berpengaruh secara positif dan signifikan terhadap efektivitas 
pelayanan, hal ini terlihat dari nilai signifikan $(0,000)<0,05$ dan nilai $t_{\text {hitung }}(4,683)>t_{\text {tabel }}(2,012)$ artinya jika ditingkatkan variabel kemampuan SDM sebesar satu satuan maka efektivitas pelayanan akan meningkat sebesar 0,663.

$\begin{array}{ccc}\text { Berdasarkan } & \text { hasil penelitian } \\ \text { dapat dibuktikan bahwa variabel }\end{array}$ kepemimpinan memiliki pengaruh yang signifikan terhadap efektivitas pelayanan. Bahkan berdasarkan penelitian ini, variabel kepemimpinan lebih dominan dibanding variabel kemampuan SDM. Hal ini menunjukkan bahwa variabel kepemimpinan dan kemampuan SDM secara bersama-sama berpengaruh signifikan terhadap efektivitas pelayanan pensertifikatan hak atas tanah pada Kantor Pertanahan Kota Tangerang.

\section{KESIMPULAN}

Berdasarkan hasil analisis yang telah dilakukan maka dapat disimpulkan sebagai berikut:

1. Variabel kepemimpinan dan kemampuan SDM memiliki pengaruh yang signifikan terhadap efektivitas pelayanan pensertifikatan hak atas tanah pada Kantor Pertanahan Kota Tangerang. Kepemimpinan dan kemampuan
SDM pada Kantor Pertanahan Kota Tangerang dinilai sangat baik sehingga efektivitas pelayanan juga tercapai dengan baik.

2. Berdasarkan uji-t bahwa variabel kepemimpinan adalah variabel yang paling dominan terhadap efektivitas pelayanan, hal ini menunjukkan bahwa kepemimpinan sesuai dengan kemampuan SDM pegawai Kantor Pertanahan Kota Tangerang sehingga tercipta suatu efektivitas pelayanan pensertifikatan hak atas tanah.

3. Berdasarkan Koefisien Determinasi diketahui bahwa variabel kepemimpinan dan kemampuan SDM secara signifikan berpengaruh terhadap efektivitas pelayanan pensertifikatan hak atas tanah

\section{SARAN}

Dari hasil penelitian yang didapat, demi terwujudnya efektifitas pelayanan sertifikat hak atas tanah pada Kantor Pertanahan Kota Tangerang maka perlu adanya peningkatan sebagai berikut:

1. Cara melaksanakan koordinasi antar petugas atau pegawai dan kejelasan dalam memberikan perintah terhadap bawahan sehingga ada peningkatan efektifitas pelayanan. 
2. Meningkatkan kemampuan SDM melalui pendidikan baik yang di dalam ruang lingkup kantor maupun yang di luar, sehingga pegawai mempunyai kemampuan yang lebih tinggi dalam melayani persetifikatan hak atas tanah.

\section{DAFTAR PUSTAKA}

Bungin, Burhan. 2003. Analisis Data Penelitian Kuantitatif. PT. Raja Grafindo Persada. Jakarta

Fathoni, Abdurrahmat, 2006. Manajemen Sumber Daya Manusia, cetakan pertama, Rineka Cipta, Jakarta.

Fitzsimmons, James A., Mona AF., 1994, Service Management for Competitive Advantage, $\mathrm{Mc}$ Graw Hill, London.

Gomes, Faustono Cardoso, 2003. Manajemen Sumber Daya Manusia, Andi Offset, Yogyakarta.

Ghozali, Imam. 2009, Aplikasi Analisis Multivariate dengan Program SPSS, Cetakan ke IV, Semarang: Badan Penerbit UNDIP.

Karjadi, M. 2009. Kepemimpinan (Leadership), PT. Karya Nusantara, Bandung

Kreitner, Robert dan Angelo Kinicki, 2008. Perilaku Organisasi, Salemba Empat, Jakarta.

Mathis, Robert L \& John H. Jackson, 2002, Manajemen Sumber Daya Manusia, jilid 2, Salemba Empat, Jakarta.

Moenir, H.A.S., 2010, Manajemen Pelayanan Umum di
Indonesia, Bumi Aksara, Jakarta.

Soetopo, 2009, Pelayanan Prima, LAN RI, Jakarta.

Sugiyono. 2004. Metode Penelitian Bisnis. Bandung: Alfabeta.

\section{Peraturan-peraturan :}

$\begin{array}{lr}\text { Peraturan Presiden Nomor } 10 & \text { Tahun } \\ 2006 \quad \text { tentang } & \text { Badan } \\ \text { Pertanahan } & \text { Nasional, } \\ \text { ditugaskan } & \text { untuk } \\ \text { melaksanakanurusan } & \\ \text { pemerintah di } & \text { bidang } \\ \text { pertanahan secara nasional, } \\ \text { regional dan sektoral. }\end{array}$

Undang-undang Pokok Agraria (UUPA) Nomor 5 Tahun 1960 tentang Peraturan Dasar Pokok-pokok Agraria. 